\title{
Kulturarv - et begreb mellem politik og information
}

\author{
Af Niels D. Lund
}

Kulturavet är bra, som sagt, för identitet, trygghet och livskvalitet. Det är bra som en minnesbank. Det är bra för orters attraktivitet, deras näringsliv och turistinkomster. Det är bra att känna till kulturav och historia för att kunna utöva sina demokratiska rättigheter och för att förstå människor från främmande kulturer. Det är bra för att befordra kulturell mångfald. Det är bra som inspirationskälla för konstnärligt verksamma personer och mer allmänt som en källa til historisk och kulturhistorisk information och estetiska upplevelser. (1)

\section{Signal og appel - kulturarv på dagsordenen}

Kulturarv dukker i dag op i flere og flere sammenhænge; det er blevet et ord der bringer mange forskelligartede fænomener på linje, trækker dem ind under samme tænkning.

Aviserne kan næsten dagligt bringe beretninger; enten om trusler som oversvømmelsen af Karlsbroen i Prag eller plyndringen af Koranbiblioteket $i$ Bagdad, eller om initiativer som flytningen af en modernistisk lufthavnsbygning i Kastrup eller det nys gennemførte revisionsarbejde med Den danske Salmebog, hvor den gamle institution skulle fornys uden at tabe sin skattede overlevering og identitetsbærende funktion. En dansk arkitekt har sat sig for at samle gamle neonreklamer, som ellers er ved at være udtjente og gå tabt; han $\emptyset$ nsker eksempler på dette kunsthåndværk fredet
- bl.a. Irma-hønen - og vil med inspiration fra udlandet oprette et egentlig museum for at holde fast i "vores danske neonarv". Et lille andels-frysehus $i$ Holm på det nordlige Als, fra 1950 og nu med fremtiden bag sig, klassificeres af det stedlige Kulturmiljøråd som en del af et ofte upåagtet kulturmiljø der som fælles kulturspor og arv søges bevares. Initiativet Golden Days of Copenhagen fra 1994 har været et illustrativt dansk eksempler på den nye eventkultur som i en blanding af faglig museumsformidling og kulturturisme har fokuseret på kulturarvstænkningen; den danske guldalder i 1800-tallets begyndelse er med biennale festivaler trukket frem til både påmindelse, fejring og tværfaglig fordybelse. Klassikerdagen der i 1999 blev institueret $\mathrm{i}$ et samarbejde mellem bl.a. Danmarks Biblioteksforening og Samrådet for De Litterære Selskaber med arrangementer hvert år i folkebibliotekerne omkring en væsentlig dansk skønlitterær forfatter (hidtil Emil Aarestrup, Kjeld Abell, Thomasine Gyllembourg, Leonora Christine) blev præsenteret som et initiativ til gunst for kulturarven. I Rønnevang sogn ved Taastrup er man i gang med ombygning af den moderne kirke - fra 1976 af arkitekt Holger Jensen - så dens indre tilnærmes en velkendt landsbykirke ud fra tankegangen at der i en posttraditionel tid er et behov for en bevidst genetablering af traditionens form.

I forskningssammenhæng er begrebet nylig dukket op i bogtitler som Den trykte kulturarv (1999) 
- til pligtafleveringslovens 300 års-jubilæum, og Vor skjulte kulturarv (2000) - udgivet af arkæologiske selskaber til H. M. Dronningens 60 års dag måske sigende nok netop officiøse celebreringsbøger, ligesom et stort dokumentarium Nationale symboler $i$ det danske rige 1830-2000 (2003) af museumsinspektør Inge Adriansen for første gang samlet præsenterer fælles kulturelt arve- og identitetsgods gennem knap 200 år: rigsvåben, mindesmærker, nationalsange, pengesedler mv.

I forbindelse med tydning og stillingstagen, forvaltning og eksponering af fortiden kan de forskellige felter i stigende grad finde næring $\mathrm{i}$ en tænkning der samler sig om kulturel arv. Begrebet har - delvis som en afløser af begrebet kulturhistorie - vundet accept overalt, næsten som et mantra for nogle netop fælles bestræbelser; i 2002 banede det sig vej til et nyt ministerielt organ Kulturarvsstyrelsen.

Signalerne ses naturligvis ikke blot i Danmark. I Sverige oprettedes i 1995 på baggrund af ødelæggelser under krigene i Bosnien og Hercegovina Stiftelsen Kulturarv utan Gränsar med henblik på indsatser når kulturejendom rammes af konflikter. En flot farveillustreret norsk turist-guide i handskerumsformat med oplistning af utallige seværdigheder og et stærkt følelsesladet forord hedder slet og ret Norsk kulturarv (2001), udgivet af en forening af samme navn. Det kan findes overalt; på de polske statsbaners hjemmeside reklameres der for de stadig anvendte gamle damptog som - i den engelsksprogede version "rolling-stock heritage". De overnationale initiativer findes mest volumin øst under FN med programmet World Heritage (fra 1972) med stærkt stigende bevågenhed, og år 2002 blev udråbt som FNs kulturarvsår. Europarådets kampagne Europa-vor falles arv løb af stablen i 1999-2000, hvortil danske bidrag var aktiviteter omkring middelalderkirker med kalkmalerier, slotte, borgruiner, haver mv. med fokus på bevaring af kulturmiljø. Tilbage i 1963 oprettedes Europa Nostra - PanEuropean Federation for Heritage som en NGOparaply for bevaringsforeninger med mottoet: No life without roots, no identity without history, no future without a past.

Eksemplerne er legio og øget kraftigt inden for de allerseneste år; institutioner, organisationer og foreninger, frivillige såvel som halv- og helofficielle, har taget kulturarv til sig som et brugbart begreb. Ledsaget af også en bred folkelig bevaringsinteresse er der fundet en art fællesnævner, som med både signal og appel på én gang kan rumme begrundelse for, legitimering af og synliggørelse af beskæftigelsen med det historiske. (2)

\section{Seks veje til kulturarvstæenkningen}

\section{Reaktion på samfundsmoderniseringen}

Skal man begrunde hvorfor termen kulturarv har vundet frem, kan man pege på en række mere generelle udviklingstendenser.

Begrebet dukker op og anvendes i takt med erkendelsen af konsekvenserne af samfundsmoderniseringen gennem de sidste ca. hundrede år. Industrialisering og udryddelse af håndværk, urbanisering og $\varnothing$ get infrastruktur, ny teknologi og massemedier, uniformering og standardisering (mcdonaldisering) er stikord til den $\varnothing$ konomiske udvikling af velstandssamfund; yderligere kan der peges på forhold som ændret arealdisponering og indhug i naturområder (man taler også om påvirket naturarv), forurening og nedbrydning af materialer (beton, papir og celluloid etc.) samt ændring af hidtidige $\varnothing$ kologiske balancer.

Udviklingen angår ikke blot forandringer i den fysiske og materielle kultur; sammen med øget både geografisk og social mobilitet gælder det også oplevelsen heraf og de dermed følgende stadig hastigere forandringer i mentale mønstre og sociale strukturer, i sprog, i familiemønstre og i religionens rolle. Et begreb som modernisme har stået for fremskridtstro og internationalisme i opg $\varnothing$ r med tradition og lokalt særpræg, ligesom videnssamfundets ekspertsystemer har afløst fx tidligere typer af bevidsthedsfællesskaber.

Inden for sociologien kan moderne samfund defineres som aftraditionaliserede eller post-traditionelle, pga. stærke ændringer i hvorledes samfund reguleres og videreføres via traditioner (normer/moral, ritualer, sandhedsformler, traditionsvogtere, kollektiv hukommelse, jfr. Anthony Giddens); traditioner forefindes ikke mere som automatiske rammer, de forudsættes nu aktivt vedligeholdt hvis de ikke skal forsvinde. 
Antagelig var det især 1970-80ernes internationaliserede mediesamfunds maksimering af samtidighed og omsætningshastighed der med fokus på ungdom, kulturindustri, livsstil, hedonisme og forbrug godtgjorde, hvorledes фjeblikket mentalt kunne få stor plads; det kaldte på en reaktion som sammen med en række politisk begrundede miljøbevægelser - i bred forstand - blev fundament for fremkomsten af den nyere kulturarvstænkning. I 1990erne kan reaktionen yderligere ses underst $\varnothing$ ttet af en art 'fin de siècle-stemning' og måske knyttet også til en samvittighedsstatus over det 20. århundredes rekord i menneskeskabte $\varnothing$ delæggelser via krige.

Kulturarv må ses i sammenhæng med opbrud, ophør eller tab af noget velkendt, desto voldsommere brud desto mere fokus på kulturarv. Den angiver et værn mod ikke blot ændringer, men også egentlige opløsningstendenser. Historie og kulturarv mobiliseres som afbigt for oplevelsen af ombrydning af hidtidige fællesskaber og værdimønstre og for at underst $\varnothing$ tte behov for historisk kontinuitet og identitetsfastholdelse (både individuelt og på gruppeniveau); der fejes op efter moderniseringen og dens hastighed - så at sige som tømmermændene dagen derpå! I kulturarvstænkningen rummes træk af en modernitetskritik og protest, og således udgør den en reaktiv bevægelse; på den anden side henregnes dog også udtryk for moderniteten som (nyere) kulturel arv, fx Arne Jacobsens bygninger og James Joyce's Ulysses.

Foruden som signalord om indsats mod helt konkrete trusler om ændringer kan man derfor i dag udmærket se kulturarv som et af de mest omfattende begreber til sikring af historisk kontinuitet og samfundsmæssige og mentale balancer med rækkevidde langt ud. Begrebet fanger en generel historisk tilstand. Tidligere har der naturligvis også været reaktive bevægelser mod samfundsmoderniseringer (fx Arts and Crafts i England omkring 1900); hvad der kendetegner den nye kulturarvstænkning er formentlig at den stærkere og mere omfattende sætter sig igennem i kraft af en institutionel organisering via politik på det kulturelle område. Står kulturarv således for reparation og fastholdelse frem for udskiftning og given los, kunne man spørge om det ikke i forhold til samfundstænkningen nødvendigg $\varnothing \mathrm{r}$ en skærpet skelnen mellem reaktiv og bevaring på den ene side og reaktionær og konservatisme på den anden side? (3)

\section{Identitets- og erindringspolitik}

En øget vægt på identitets- og erindringsspørgsmål har typisk ledsaget den nye fokus på kulturarv. Politiske bestræbelser og tiltag omkring identitet kan forstås som fremme af den faktiske mulighed for og den legitime fornemmelse af at høre til, få råderum og suverænitet og være synlig; de kan sættes igennem på både individ- og større eller mindre gruppeniveau, og de har både et defensivt og et offensivt ansigt. Typisk accentueres behovet for identitetspolitik af (oplevelse af) stærke forandringer i vilkår eller normer, eller måske ligefrem af trusler mod disse. Identitetsforestillinger har spillet en meget væsentlig rolle for opbygninger af nationer som enheder (jfr. foedreland, modersmål) - med egentlig nationalisme som den mere voldsomme udformning. I nyere, især europæisk, historie har helt centrale både politiske og mentale mønstre være tegnet i identitetsbilleder, og ikke mindst anset som en del af en politik på det kulturelle område - således i slutningen af 1990erne fx også understreget af danske kulturministre.(4) I den postkoloniale tid angår det essentielt de nye selvstændige nationer og får fx også betydning i forhold til de nye vilkår som landene i Østeuropa har fået efter Murens fald. På den anden side tegner nye overnationale sammenhænge andre mønstre, således fører fx også EU identitetspolitik.

I principielt alle gruppeforhold kan den ytre sig, typisk i bevægelser der vil og/eller får mulighed for at markere sig samfundsmæssigt friere end under hidtidige forhold; kvinder, zionister, sorte, homoseksuelle, hjemmetyskere i Sønderjylland kan føre identitetspolitik. Men også fx tidligere kz-fanger, Woodstock-veteraner, Christinanitter eller Ollerup-elever kan gøre det for at understrege væsentlige tilhørsforhold. Ofte underst $\varnothing t t e s$ en sådan gruppe-selvforståelse af bestemte markeringer, ikoner, fejringer etc. Den stigende accept af det legitime heri kan ses sammen med udbredelsen af det kulturelle demokrati, og øget fokus på menneskerettigheder og på minoriteters vilkår har været en væsentlig faktor. Følgen har bl.a. 
været mange opbrud på tværs af etablerede grupperinger og hidtidige enhedskulturer, typisk de nationale.

Det væsentlige for kulturarvssammenhængen er at fortiden og historien bliver afgørende for identiteten: desto længere tilbage den kan begrundes desto vægtigere fremstår den. En bestemt også følelsesmæssig orienteret - selvforståelse fremmes af fastholdelsen af en fælles erindring; sådanne erindringsfoellesskaber kan fremmes via aktive bestræbelser, med selektion af bestemte begivenheder, traditioner, steder, skrifter, personer etc. (og eksklusion af andre) og med prægning eller styring af fortolkningen heraf (men også med myter og illusioner). Man kan tale om at føre erindringspolitik som en del af en identitetspolitik; nationer, lokaliteter, grupperinger, individer kan gøre det. Aktiviteter i utallige lokalhistoriske foreninger, st $\varnothing$ ttekredse mv. har erindringspolitik som mål og ramme, foreningen Fregatten Peder Skrams Venner fra 1996 kan være et eksempel. Den gennemdokumenterede TV- og videoserie Plads til os alle (2000) som den danske arbejderbevægelse fik lavet om sin historie var et identitets- og erindringspolitisk indlæg - og det fremkom netop på et tidspunkt hvor bevægelsens historiske rolle skulle understreges over for voldsomme forandringer i dens grundlag i nutiden.

De erindringsspor der ifølge denne udvikling trækkes frem bliver stadig flere og mere mangfoldige; alle grupper kan formulere deres særlige identitetsmæssige arv og kræve den respekteret, i princippet er alle erindringsfællesskaber omkring overført og fastholdt historisk bevidsthed hver for sig lige gyldige. Kulturarv kommer derved i pluralis og bliver fra et samlende synspunkt sværere overskuelig. (5)

\section{Rummeligere historiebegreb}

Udviklingen af historiefaget er gennem de seneste årtier kendetegnet ved udvidelse af interesseområdet. Begrebet kulturhistorie (historisk antropologi eller historisk sociologi) har vundet stadig større udbredelse frem for politisk og $\varnothing$ konomisk begivenhedshistorie, og et bredt syn på studiet af civilisations- og mentalitetsprocesser har også suppeleret traditionel national historie, jfr. såkaldt bindestregshistorie (kvinde-, idræts-historie mv.).
I den $\varnothing$ gede mangfoldighed af teorier og metoder findes tydelige omvægtninger; således ses historie ikke blot som et fag om fortidens realiteter der 'autoritært' produceres og udbredes af videnskabsfolk på et kognitivt grundlag og ud fra objektivitetsidealer, systematik, specialisering, kausale forklaringer og som er politisk neutralt; nok så meget ses det som et felt der konstant angår alles hele livsverden og hverdag, som uafbrudt og i dialog medproduceres af alle ud fra også oplevelser, følelser og subjektive vinkler og som er politisk og handlingsmæssigt reflekteret. Der har været fornyet fokus på netop begrebet erindring (både individuelt og gruppemæssigt), som understreger at fortiden ikke blot tilnærmes nøgternt og analytisk dokumenteret, registreret og generaliseret på baggrund af teorier af fagfolk - dvs. historie som en repræsentation af fortiden, men også må respekteres som noget der bæres af alle, umetodisk sanset og følelsesbåret, integrerende og inkluderende og som noget sårbart, måske sakralt: 'historien tilhører mig' - dvs. historie som et bånd til fortiden.

En sådan større rummelighed blandt historikere, næret af anfægtelser over for både udviklingstankegangen og historieskrivningens videnskabelighed, kan ses dels som en imødekommenhed over for befolkningens almene interesse for og medskaben i historie, dels sammen med en både ændret og $\varnothing$ get interesse for formidling. Med et begreb om historiebevidsthed - forstået som samspillet mellem menneskers fortidsfortolkning, nutidsforståelse og fremtidsforventning - der tager udgangspunkt i nutiden og ikke i fortiden, får spørgsmål om forvaltning af arv også umiddelbart både nye forståelsesrammer, moralske kategorier og flere nuancer tilført; det gælder ikke mindst begrebet kollektiv erindring. Blandt faghistorikere, arkæologer mfl. er der mange forbehold over for både selve begrebet kulturarv og den omsiggribende brug af det - det er en udfordring; men mange af de nyere diskussioner inden for historiefag og fx museologi har omvendt beredt vejen for den skærpede forståelse for og brug af fortiden som den nyere kulturarvstænkning bygger på. (6)

\section{Institutionel vakst}

Udvikling af institutioner sker bl.a. i takt med udvikling inden for ekspertsystemer, med arbejds- 
deling og fagdifferentiering, og med ansættelse af uddannede fagfolk samt etablering af råd og nævn. På det kulturelle område er foregået en nylig stærk vækst i institutionsopbygningen i tråd med en generel øget samfundsmæssig vægt på kulturpolitik og i følge med udviklingen af både videns- og fritidssamfundet. Staten har især gennem 1990erne haft fokus på udbygning og fornyelse af de store nationale institutioner; men med decentralisering og demokratisering af kulturområdet har udbygningen i de seneste årtier også fundet sted i regioner, amter og kommuner, hvor kulturel politik er blevet lokalt prestigiøst udviklingsparameter. Også væksten i institutioner for den kollektive hukommelse har været iøjnefaldende; lokalarkiver er st $\varnothing t$ etableret siden især 1970erne og tilsvarende nye former for historiecentre, udstillingssteder og forskelligartede mindre museumsdannelser; genindretninger af gamle bagerier, vandmøller og herregårde er foretaget, og samlinger af tegneserier, veteranbiler, leget $\varnothing \mathrm{j}$ sdukker mv. er tilgængeliggjort - med større eller mindre grad af statsanerkendelse og -støtte; hertil kan lægges realisering af forskellige mindesteder i berømte kulturpersoners fødehjem eller boliger. Den stigende aktivitet, hyppigt med initiativer fra og inddragelse af ikke-fagfolk, spejler på den ene side en ikke aftagende bred historisk interesse, men har på den anden side også nærmet sig en art historie-marked - med den engelske betegnelse: heritage industry. Nye muligheder via hjemmesider har bidraget til synliggørelsen.

Eksemplerne er legio. Vikingeskibsmuseet i Roskilde er udbygget fra den første kirkelignende bygning (1969) til nu et helt marinarkæologisk arbejdende besøgsområde. Først blev Johannes Larsen Museet åbnet for offentligheden i 1986-87, som mindested og lille kulturmiljø ud fra en restaureret bolig og atelier, dernæst blev det med store udbygninger, i 1990 og igen i 2001, omlagt til kunstmuseum med vægt på fynske malere, udstillingsbygning og koncertsted som en del af Kertemindeegnens Museer. Forfatteren Emil Aarestrups hus i Nysted blev i 1990erne købt af en dertil etableret lokal forening og istandsat til fremvisning og arrangementer relateret til guldalderen. I større målestok har andre forfattere fået deres klassikerstatus underbygget med egne tilholdssteder, Ibsen-senteret i Oslo (1993) eller Budden- brookhaus - Heinrich und Thomas Mann Zentrum i Lübeck (1993) - i disse tilfælde ligeligt som center med bibliotek og arkiv for videnskabelig forskning og som museumssted for en bredere offentlighed.

De mange nye institutionaliseringer er resultat af nogle værdistyrede aktiviteter og forudsætter værdimæssig accept; med stigende mangfoldighed fremstår de som 'kulturelle selvportrætter' der også bliver langt mindre entydige, overskuelige og kontrollerbare end hidtil. Alene den $\emptyset$ gede kvantitet kan rokke ved hidtidige kommunikations- og interaktionsmønstre omkring såvel viden om som holdninger til fortiden. Foruden nye kontaktflader og ændrede prægninger har disse institutioner også fået stigende $\varnothing$ konomisk og forvaltningsmæssig vægt i samfundet. Der er næppe tvivl om at denne udvikling har fået både næring og retning fra kulturarvstænkningen; de ofte store fondsst $\varnothing$ ttemidler er blevet genereret ud fra samme begrundelse. Overhovedet er der dermed blevet skubbet voldsomt til fornyelsen af især museumstænkningen, med øget aktivisering, nye formidlingstiltag og forskellige synergieffekter til følge. En særlig form for kulturarvs- og bevaringstænkning i de seneste tiår har ligget i genbrug af ældre (industri)bygninger som nyindrettede kulturinstitutioner, fx Brandts Kloedefabrik i Odense, Østre Gasvaerk i København og kunstmuseet Tate Modern i London. (7)

\section{Globalisering}

Med globaliseringen er der sket en sammentrækning af både tid og rum, og en større og stadig hastigere interaktion omfatter verdens områder såvel fysisk som informationsmæssigt i kraft af medieteknologi (television og internet). Rejser, turisme og især befolkningsmæssig migration har medført nye kulturblandinger og $\emptyset$ get multietniciteten mange steder. Det traditionelle eurocentriske verdensbillede har ikke kunnet opretholdes, og afkolonialiseringen efter Anden Verdenskrig blev ledsaget af mange ændrede internationale relationer og organiseringer både politisk og økonomisk; fremtrædende i 1900-tallet har også været en stigende og homogeniserende dominans fra USA, især på erhvervs-, kultur- og medieområdet. Spændinger med udspring i religion er på det allerseneste øget på verdensplan - af nogle 
kaldet egentlige konfrontationer mellem civilisationer.

Når internationalisering og globalisering således opløser traditionelle rumlige og geografiske entiteter, fremkaldes et pres på modsætningen: den mere lokale forankring. Der kommer nye udfordringer til i hvilket omfang og hvorledes både fysiske miljøer, kulturer og mennesker er stedbundne, og til hvorledes dette fastholdes. Hvis globaliseringen er tidens ånd, kunne man tale om at kulturarvstænkningen snarest reaktivt forholder sig til stedets ånd? Migrationen er antagelig blandt de største udfordringer til den hidtidige selvforståelse på nationsniveau der - især i europæisk tænkning - har bygget på en (forestillet) enhed af sprog, nation, kultur, historie og religion og natur. I Danmark kunne det eksemplificeres med spørgsmålet om hvorvidt en hævdvunden del af dansk tradition som de romanske stenlandsbykirker fra 11-1200-tallet betragtes som kulturarv af den indvandrede muslimske befolkning.

På den anden side udtrykker FNs nævnte World Heritage-program dog at erkendelsen af den hastige moderniserings konsekvenser også er et fælles globalt anliggende. Sikring af at vigtige og særegne dele af både den materielle og immaterielle kultur (og af natur) og af vidnesbyrd om fortiden ikke ændres til ukendelighed eller går tabt vedkommer i princippet alle ligeligt - i en balance med internationaliseringens gevinster omkring velfærd; det er fx anslået at omkring $90 \%$ af nu anvendte sprog vil blive udryddet/forsvinde inden for de næste 100 år. Dog er det også påpeget at hele denne kulturarvstænkning på globalt plan grundlæggende er udtryk for en vestlig tænkning; andre samfund kan tænke helt anderledes omkring deres fortid, og usamtidigheden kloden over kan dermed være nok så stor. (8)

\section{Kulturarvsturisme}

Det ligger lige for at fremhæve turismen som en faktor knyttet til kulturarvstænkningen. Turisme voksede i 1900-tallet til et stort felt og vigtigt erhvervsområde, for nogle lande et hovederhverv $\varnothing$ konomisk set. Kulturturisme er den del der anvender kulturelle elementer som attraktion for rejsemål, og herunder taler man særskilt også om kulturarvsturisme (heritage tourism).
Tidligere tiders rejseaktiviteter kunne indeholde historien som mål og formål: den religiøse pilgrimsrejse til hellige oprindelsessteder, aristokratiets dannelsesrejse til kulturelt vigtige steder i 1700-tallet og borgerskabets (romantisk inspirerede) turisme i 1800-tallet, hvor især landskaber og landsbyer fremstod som bagudrettet alternativ til industrialisering og urbanisering. Den moderne masseturisme har efter forskellige forskydninger i stigende grad indarbejdet fortiden; historiske levn, ruiner, mindesmærker, kulturminder udpeges og rekonstrueres som seværdigheder, og museer vokser op omkring dem, kulturlandskaber rendyrkes og udbygges oplevelsesmæssigt i kombination med kommercielle formål.

I et stort og glidende spekter kan det antage karakter af museificering af fx gamle udskænkningssteder i rådhuskældre, af fremførelse af lokale skikke i kopier af antikverede gevandter, af genuin egentlig bevaring af herregårde eller et bymilj $\varnothing$ som Firenzes eller af mindesteder som Adolf Hitlers Berghof i Obersalzberg eller Mozarts fødested der st $\varnothing t$ stigende åbnes for bes $\varnothing$ g. De gennem de senere årtier genopbyggede bykerner i fx Wien, Warszawa og Poznan, der blev stærkt $\varnothing$ delagt under Anden Verdenskrig, kan eksemplificere hvorledes nationale ambitioner kan forenes med turisme-muligheder. Ofte kan det være svært at dechifrere og differentiere, dels hvad der er henholdsvis oprindeligt og rekonstrueret, dels hvilke formål der ligger bag fastholdelsen af fortiden; men oplagt er det at den kulturelle arv træder i en ny karakter i mødet med den moderne turisme. Masseappellen kan bidrage til at nedbryde kulturelle hierarkier (måske har især den uddannede middelklasse taget kulturarvsturismen til sig?); men skal fortidslevn 'virke' som kulturarv for tilrejsende turister i princippet alle steder fra, fordrer det en medieren af det fremmedartede og det fortrolige, hvilket ofte kan blive ensbetydende med standardisering, friktionsløshed og laveste fællesnævner, der forbliver udifferentieret og uigennemskuelig. Grænsen mellem distræt fornøjelse og indsigtsbåret tilegnelse ligger næppe fast eller er ens for alle turister; ofte ledsages seværdighederne dog af en information i rejseskildringer og guides der er faglig gedigen historieoplysning. 
Hvor historiske rum og rammer er attraktionerne, imødekommer de formentlig et behov for rum der adskiller sig stærkt fra nutidens rum; den visuelle, stemningsbårne og æstetiske aura skal opsluge og understrege sammenhængen mellem flytning i sted og flytning i tid. Historieturistens mål er (forestillingen om) noget oprindeligt, autentisk og ægte, en søgen efter kontinuitet og stabilitet under en omskiftelig modernitet, og hendes rejse får derved en rituel funktion for en art hjemvé-følelse. Når rejsen anvendes til en rumlig tilbageflytning, placeres det historisk autentiske dermed som et andetsteds (- det historiske, rekonstruerede rum vikarierer måske for et udvisket begreb om tid?). Denne dobbelte flytning er historieturistens imperativ; den er ikke nødvendig for at blive historisk oplyst, men nødvendig for oplevelsen. Turisten rammes da også af bl.a. det paradoks at hun ikke kan få indfriet sin oplevelse af fx Gudhjems eller Skagens oprindelige (ureflekterede) hverdagsbymiljøer, samtidig med at disse skal rumme store mængder af (reflekterede) medturister.

Moderne turisme angiver med sådanne både eksplicitte og implicitte sammenhænge mellem $\varnothing$ konomi og følelser og mellem individ og masse nogle af de mest interessante begrundelser for hvorfor kulturarv er et så både tiltrækkende og problematisk fænomen i dag. Den stigende eksponering af kulturarv spejler måske overhovedet et turistmæssigt forhold til historie?

I UNESCOs anvendelse af cultural heritage indgår der en strategisk dobbelthed af sikring og eksponering; værn af kulturværdier har ingen begrundelse hvis de ikke kan studeres og nydes, og investeringerne til restaurering og bevaring af World Heritage Sites skal tjenes hjem via direkte indtægter fra turister eller via generel opmærksomhed og prestige. Der er således også udviklet en art speciel 'kulturarvs $\varnothing$ konomi' med offentlige instanser, erhvervslivssponsering, fondsmidler og partnerskaber. Aktuelt er Christiansfelds ældste, fredede bykerne (plan og bygninger) fra 1770erne på UNESCOs observationsliste, og midlerne til restaurering/rekonstruktion af den oprindelige skikkelse (samt projekt om et tilhørende formidlingscenter) kommer bl.a. fra den almennyttige Realdania-fonden, stiftet 2000, under dens fokusområde: sikring af den historiske arv. (9)
De seks her skitserede udviklinger - de seks veje er ingenlunde ganske nye, men de synes hver for sig intensiveret, og netop set i sammenhæng bidrager de til at udkrystallisere de seneste års tænkning om kulturarv.

\section{Kulturarvsbegrebet}

Kulturarvstænkning ses således her som samlebetegnelse for et nyt aktiviseret forhold til fortiden fremkaldt i samspil med en række samfundsmæssige tendenser. Selve ordet kulturarv er dog så lidt kodificeret at det først for helt nylig, og ret nødtørftigt, optræder i leksikalske opslagsværker: Gads historieleksikon (2001) og Supplementet til Den Store Danske Encyklopaedi (2002); brugen af ordet er løbet forud for den (teoretisk) begrebslige bestemmelse. Spørgsmålet er af hvilken art begrebet er og hvor konsistent det kan gøres. Er det deskriptivt eller normativt? Er det et præcist fagbegreb, evt. videnskabeligt, et didaktisk, et kulturelt eller et politisk begreb?

Det er blevet fremført at det er et meget relativt begreb og et begreb med mange paradokser i sig,(10) hvilket står i kontrast til den tilforladelighed og de typisk entydigt positive konnotationer, hvormed det nylig er blevet så stærkt udbredt. I international sammenhæng, fx med UNESCOkonventionen, etableredes det nyere kulturarvsbegreb allerede i 1970ere, men vandt ellers især frem i 1980erne inspireret fra England hvor cultural heritage blev indkredset som $\mathrm{fx}$ "That which a past generation has preserved and handed on to the present and which a significant group of population wishes to hand on to the future"(11) - ikke mindst knyttet til bevaring af truede herregårde.

Med kulturelementet indbefattes i begrebet en stor og standende diskussion af selve kulturbegrebet, således en mere snæver betydning af kultur som forbeholdt aktiviteter og manifestationer inden for traditionelle kunstneriske ytringsfelter: billedkunst, litteratur, arkitektur mv, over for et bredere (etnologisk) kulturbegreb der omfatter menneskets hele livssituation og vilkårene for kollektiv identitet: viden, tro, kunst, moral, love og skikke mv.(12) Den sidstnævnte betydning synes den mest frugtbare, og den knytter sig dermed også tydeligere dels til begrebet kulturhistorie, der 
frem gennem 1900-tallet vandt accept som en mangeartet udvidelse af historietænkning og -fag, dels til en tværfaglig tænkning med bidrag fra de mange (også videnskabelige) kulturfag der efterhånden er etableret.

Nogle har i diskussionen søgt et skarpt skel mellem historie og kulturarv, således den engelske historiker David Lowenthal:

"We are necessarily as ignorant of other peoples' heritage as they are of ours. This is the crux of what distinguishes heritage from history. To serve as a collective symbol heritage must be widely accepted by insiders, yet inaccessible to outsiders. Its data are social, not scientific. Socially binding traditions must be accepted on faith, not by reasoning. Heritage thus defies empirical analysis; it features fantasy, invention, mystery, error.” (13)

Han finder kulturarv svært at håndtere videnskabeligt: Medens historie som fagbegreb traditionelt vægter en nøgternt diskuterende, kildedokumenteret kognitiv tilgang til fortiden med vægt på kronologi og (kausal)forklaring og med sigte på en intersubjektiv (universel) viden der er uafhængig af modtagerens ståsted, så lægger kulturarvsbegrebet op til et mere situativt udvalg af fortiden grundet på erindring, indlevelse og loyalitet og hvor der med indiskutabel accept og højtideligholdelse kan lægges bund under hele den nutidige livsverden; hver har sin egen kulturarv med eget ståsted, og tilgang og adkomst er kun intersubjektiv så langt den deles af andre med samme valgte tilhørsforhold.

Med sådanne mere irrationelle indfaldsvinkler trækker en bestemmelse af kulturarv snarest i retning af en socialpsykologisk og symbolsk størrelse grundet på tro og accept. Når elementet arv har vundet frem som erstatning for fortidslevn eller fortidsminde, hænger det sammen med at arv er noget samtidigt og associerer til aktuelle ressourcer og rigdom, en betroet kapital som den forbundne arving har pligt til at forvalte aktivt, medens levn eller minde associeres til noget 'd $\varnothing \mathrm{dt}$ ' eller blegnende, tilbagelagt eller inaktuelt og snarest knyttet til objektet. (14)
Arv understreger en overtagelse og noget bindende for nutidens forhold til fortiden, noget akkumuleret, der indicerer forestilling om fundament og med sin manglende specificering lægger op til et næsten organisk helhedssyn - desto mere desto flere det udstrækkes til at omfatte; typisk i første person pluralis som 'vi' og 'vores' peger kulturarv normativt på videreførelse af samfundet.

Ikke mindst de følelsesmæssige associationer er vigtige, som den svenske etnolog Orvar Löfgren siger det:

"Kulturarv innebär alltid en emotionell laddning - på gott och ont. Varje gång en byggnad, ett landskap, en text, en melodislinga utnämns till kulturarv ändrar det karaktär - det sker en sakralisering eller emotionalisering. I presentationen av kulturarv återfinnns en stark betoning av 'vi' och 'vårt'. Mycket kan vi vara oeniga om, men kulturarvet vilar tryggt $i$ et gemensamt förflutet, där nuets konflikter inte bör ha tillträde.”(15)

Således peges der også på et kollektivt mentalt tryghedselement; kulturarv appellerer til en psykologisk oplevelse af fortidens skærmende tilstedevær i forhold til en foranderlig nutidsverden. Resultatet kan blive at der trækkes sammen indad og dermed også afgrænses i forhold til andre og til noget fremmed.

Frank Birkebæk har understreget det helt igennem relative ved begrebet. Kulturarv er tidsmæssigt relativt dels i den forstand at mennesker ikke altid har haft det samme syn på fortid og historie og på arv og bevaring, som man har nu, dels fordi det er tilfældigt hvad der har overlevet/er overleveret frem til vores nutid, og som vi i dag kalder kulturarv og bevarer. Langt det meste har indtil for 100-150 år siden måttet "klare sig selv", og der er tilfældigheder knyttet til meget af hvad vi finder eller opdager - $\mathrm{fx}$ via arkæologiske udgravninger; ingen ved hvor meget er fortsat skjult og hvad det evt. 'er værd'. For at afgøre hvilke dele af nutiden der vil være bevaringsværdige og i fremtiden kan anses som kulturarv, forudsættes et tidsperspektiv og nogle sammenligninger med hvad vi allerede har arvet og $\varnothing$ nsker bevaret fra fortiden - og det var som nævnt relativt. I princippet kan kun efter- 
tiden afgøre hvad der er den bevaringsværdige kulturarv fra det der er nutid nu; en fremtid kan prioritere og fortolke ganske anderledes i en stadig relativitet. Det må således give nutidens bevaringstænkning ganske store problemer.

Rumligt og geografisk er kulturarv også relativ. Nogle kulturer - nationer, regioner, lokaliteter, etniske grupperinger etc. - vil prioritere noget, andre andet, der er ikke de samme værdier og vurderinger overalt. I multietniske og flerkulturelle samfund bliver der således andre udfordringer, og snarere end fx 'dansk kulturarv' kunne man tale om 'kulturarv i Danmark'. Meget peger på at den nu fremherskende brug af kulturavsbegrebet primært er af vestlig karakter og knyttet til en historieopfattelse med prioritering af det materielle (fysiske genstande/omgivelser), frem for andre kulturers måske mere immaterielle værdier.

Det relative gælder tillige den sociale eller standsmæssige differentiering: adel, borgere, bønder, håndværkere, arbejdere mv.; alle grupper har et legitimt $\emptyset$ nske om at fastholde og præsentere deres fortid og dermed identitet. Det kan være nødvendigt at betone fordi kulturarv ofte associeres med arven fra de socialt set stærke grupper; normalt er det deres levn og gerninger der (i det politiske styrkeforhold) er blevet prioriteret og bevaret.

Disse relative forhold understreger hvorledes der konstant foretages valg uden i princippet nogen endelig sandhed; kulturarv spejler et stadie i en søgen efter og fortolkning af fortiden, andre vil eller kan senere prioritere og fortolke anderledes. Det rejser spørgsmålet om hvem der foretager eller overlades disse valg og prioriteringer, og dermed spørgsmålet om autoritet. Typisk er denne autoritet overladt til en videnskabelig fagekspertise, men i et demokratisk samfund skal den også forenes med de socialt betingede valg og de emotionelle ladninger. Mange historikere har derfor hidtil været tilbageholdende omkring kulturarvsbegrebet; det videnskabelige kan være svært at håndtere sammen med det relative og med hvad der er samfundsmæssigt fremkommeligt.

Den svenske historiker Svante Beckman har bestemt kulturarvstænkningens kompleksitet ud fra hvilke vardier, der kan begrunde bevaringen af kulturarv; således indskrevet i et værdikort delt efter handlingsrelevans kontra oplevelsesrelevans og kognitiv værdi kontra emotiv værdi (figur 1):

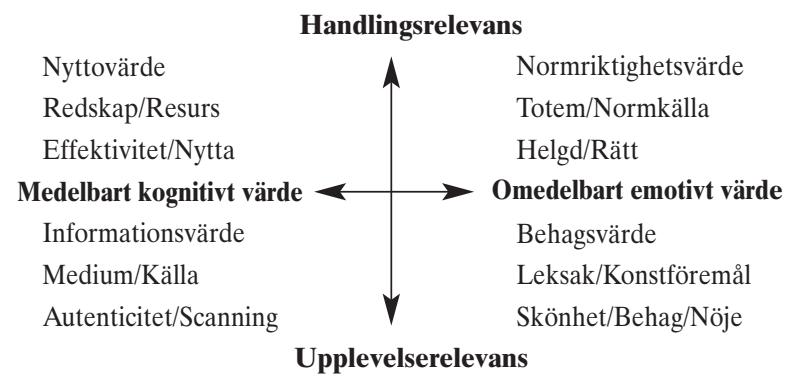

Figur 1: Kort over vardier til begrundelse af bevaring af kulturarv - Beckman (1999)

Man bevarer kulturarv fordi den har en informationsvardi, den er som levn en kilde til viden (sandhed) og dermed knyttet til oplysning, uddannelse og erkendelsesinteresse; her er det typisk fagekspertisen der begrunder kulturarvens væsentlighed. Den har en ligeledes fornuftsbetonet nyttevardi som ressource i samfundet, herunder som grundlag for erhverv og beskæftigelse, fritidsanvendelse og turisme; denne værdi får større og st $\varnothing$ rre betydning (desto ældre, mere særegen og uhåndterlig desto flere hænder og kroner medgår der til opretholdelsen) og knytter sig til andre interessenter end oplysningens. Kulturarven har en behagevardi knyttet til æstetik og kunst, fornøjelse og oplevelse; også den værdi vinder stadig større legitimitet i takt med samfundets velstand. Endelig har kulturarven en vardi som norm og rettesnor for etisk vurdering, som symbolsk udtryk for et givet samfund og dets selvforståelse; Beckman taler om totem og helligdom der hæges om med ærbødighed og pietet, endog fortryllelse, og han finder at denne mere irrationelle værdi på én gang er både den væsentligste og den sværeste at formulere og behandle (også for videnskabsmændene); her brænder det for alvor på når der tales om truet kulturarv, her kan det være helligbrøde hvis man lader noget gå tabt.(16)

Når man skal tage stilling til kulturarv, må der tages hensyn til alle de fire felter. I et andet værdikort tydeligg ør Beckman hvilke værdier og funktioner der kan identificeres i forhold til en 
kulturarvspolitik, her igen via en sondring mellem det kognitive og det emotive samt mellem samfundsniveau og individniveau (figur 2)

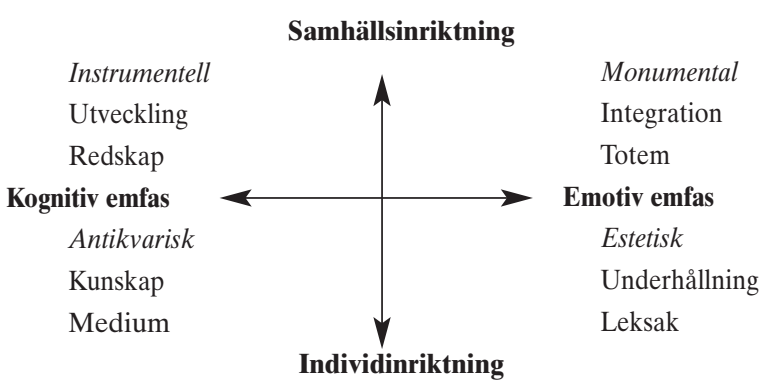

Figur 2: Kort over kulturarvens begrundelser i en kulturarvspolitik - Beckman (1999)

Begrundelserne for en politik omkring kulturarv ligger således på fire felter:

Den instrumentelle hvor kulturarv for samfundet er ressource og redskab for $\varnothing$ konomisk udvikling, herunder fx i konkurrence med andre kulturlande. Den monumentale hvor den primært indadtil tjener som socialt og identitetsmæssig sammenhængsskabende størrelse. Den antikvariske hvor systematisk viden og kundskab om fortiden for den enkelte er i højsædet. Den astetiske hvor ligeledes det enkelte menneske henter oplevelse, nydelse og glæde. Vigtigt er det at se på kortets diagonale akser også: den ene - mellem det monumentale og det antikvariske - rummer den traditionelle argumentation og legitimering; den anden mellem det instrumentelle og det æstetiske - synligg $\varnothing \mathrm{r}$ fx kulturturarvsturismen i kombinationen af individuel underholdningsværdi og samfundsmæssig udviklingsværdi og er måske den, der vil blive vægtet i fremtiden sammen med $\varnothing$ get markedstænkning omkring fortiden som oplevelse. Moderne kulturarvspolitik er spændt ud mellem disse fire felter der kan være svære at få i balance. (17)

Det relative, valget, det følelsesbårne og det hellige er således vigtige kendetegn ved kulturarvsbegrebet; derfor synes det mere frugtbart at betragte det som et normativt begreb frem for et deskriptivt. "...there is no objective judgement of heritage interpretation, only judgements based firmly on ethical positions" som den engelske geograf Peter Howard har anført.
Kulturarvsbegrebet omfatter de fælles referencer og den kollektive identitet og hukommelse. Således udtrykker det den historiske dimension af samfundsudviklingen; det sammenfatter hvad der kan og skal sikre balance og kontinuitet inden for en kultur i bred forstand op mod de udviklingsmuligheder moderne (teknologiske) samfund har - synet bagud samtidig med synet fremad. Det bruges som udtryk for en kulturs behov for opretholdelse, understøtning og selveksponering; kulturarv er ikke noget der er, det skabes hele tiden i en diskussion og ud fra valg der er fremtidsrettede. I et demokratisk samfund udtrykker det en vedkendt accept af og en 'fredelig sameksistens' med tidligere hegemonier (fx kirke, fyrstemagt, nationalstat, race- og klassetænkning) og deres betydning for nutiden.

Et nyt norsk forskningsprojekt "Fortidens gaver og nåtidens grenser" søger eksempelvis at begribe kulturarv i relationerne mellem brud og kontinuitet (historiske udviklinger), mellem identitet og forskel (sociopolitiske brydninger) og mellem del og helhed (symbol- og repræsentationsforhold). (18)

Derfor synes det mest frugtbart at se kulturarv som et politisk orienteret begreb der i moderne samfund aktiveres omkring et refleksivt forhold til fortiden i bred kulturel forstand. På nationsniveau eller blandt andre større eller mindre grupperinger indebærer det nogle sk $\emptyset$, prioriteringer og valg der er underlagt både demokratiets kompromisfelter og retorik og dets aktive vilje og evne til at tilvejebringe de til formålet påkrævede ressourcer; eksempelvis er det ikke alene elitens arv der skal tilgodeses. Til kulturarvens politiske felt må henregnes foruden oplysning, forskning og undervisning adskillige andre både samfundsmæssige organiseringer og symbolske adfærdsformer; aktørerne er således både politikere, fagspecialister, kulturformidlere og den almindelige befolkning.

\section{Kulturarvspolitik}

Hvis nutidens samfund har $\varnothing$ konomiske og teknologiske muligheder for at 'modernisere sig væk fra fortiden', så 'dør' fortiden stadig hurtigere, med mindre man forholder sig aktivt til den. Hvis forholdet til fortiden har ændret sig - fra noget tradi- 
tionsindlejret og medlevet til noget der i kraft af moderniseringen og dens hastighed faktisk er blevet 'fremmed land '(Lowenthal) - så kræves der nye valg og initiativer for at holde fast i den, nogle der formålsbestemt og virksomt skal sikre at den ikke forsvinder, men bevares, restaureres, genudgives, aktualiseres, fremvises etc. Hvordan operationaliseres sådanne tilstande og bliver grundlag for politik?

Foranstaltninger til bevaring, fastholdelse og overlevering er naturligvis ikke nye; langt tilbage er de kendt, typisk som magthaveres (fx fyrstestaters) behov for legitimering og symbolfremvisning. I løbet af 1800-tallet løb den historiske tanke sammen med dels den romantisk inspirerede nationaltænkning og dels opbygningen af demokratiet; den borgerlige nationalstat overtog bygninger, samlinger, biblioteker og arkiver mv. fra en tidligere kirke- eller fyrstemagt, og den tilvejebragte forestillinger om en enhed af folk, nation, stat, historie, kunst, kultur samt religion og natur. Nye former for bevaring, opbygning af museer og $\mathrm{fx}$ fredning kom til i en stadig udbygning; man fik tydelig konturen af en overordnet politisk kulturstatstanke: det er kulturen der skal give staten mening ved hjælp af overindividuelle institutioner som repræsenterer kollektive værdier; (19) tanken spillede ikke mindst omkring 1900 en betydelig rolle i konkurrencen mellem nationer, hvad enten denne fandt udtryk i geopolitisk imperialisme eller i verdensudstillinger.

Det er heller ikke nyt at der har været bestræbelser som har forholdt sig reaktivt til samfundsmoderniseringen; kulturbevarende initiativer har fundet vej når (oplevelsen af) stærke forandringer fik hidtidige grundlag til at skride: hjemstavnsforeninger og frilandsmuseer dukkede op når et kulturmiljø begynder at skifte karakter, bygningsbevarings-foreninger når udviklingen krævede nybyggeri, humanistiske dannelsesgymnasier når industrisamfundet bankede på etc.

1800-tallet skabte således traditioner for traditionsvedligeholdelse, og der har været lovgivning og institutioner til bevaring, værn og sikring; men 1900-tallets fremtidsorientering med opbygning af velfærdstater og med mentale moderniseringer efter verdenskrigene betød også en relativ svæk- kelse af disse traditioner. Da hele det kulturelle område tydeligere kom på den politiske dagsordenen ved århundredets midte - det danske kulturministerium oprettedes i 1961, var det med hovedfokus på de kunstneriske udtryksfelter og den samtidige demokratiske formidling heraf; blikket var i mindre grad rettet mod historien. De sidste ti-tyve års kulturarvstænkning synes heroverfor at markere en omvægtning; kulturpolitik satser nu på kulturarven som en stadig vigtigere del. Der sker en intensiveret fornyelse af de ældre spor, en politik for kulturarv søger efter mere sammenhæng i håndteringen af forholdet til fortiden, og nye institutionsdannelser dukker op. Det finder sted som en generel international udvikling; eksempelvis fik New Zealands kulturministerium tilført betegnelsen i 2000 - Ministry for Culture and Heritage.

Det har været påpeget at et samfund eller en stat kan have brug for en samlet egentlig historiepolitik,(20) indtil videre synes i hvert fald en politik for den kollektive erindring og kulturarven stærkt på vej. Som politisk felt indebærer det spørgsmål om holdning og valg, og desto tydeligere desto mere det følelsesbårne element træder frem. Hvis man skal erstatte hvad der tidligere var en mere integreret traditionsbundet forbindelse til fortiden, kræver det nyformulering af spørgsmål som: Hvilke brud/forstyrrelser af historisk kontinuitet har effekter så stærke at der må gribes ind? Forsvinder hidtidige kollektive symboler, og hvor langt kan de undværes? Kan kulturarv være et grundlag for et individualiseret velfærdssamfund? I denne holdnings- og værdiafklaring må der også ske en balancering af fx de fire ressourceegenskaber som Beckman ovenfor blev citeret for. Endvidere formuleres det stadig tydeligere at kulturarvsbegrebet også rækker fremad; der må tages stilling til hvad der skal være kommende generationers arv fra nutiden.

I den politiske udmøntning, der fremdeles angår prioritering af ressourcer, vil en lang række spørgsmål skulle skærpes. Det drejer sig om hvor langt hidtidige bestemmelser af kulturpolitikkens områder - typisk knyttet til et mere eksklusivt kulturbegreb - vil binde nyformuleringen af en kulturarvspolitik, hvilke andre områder der evt. må inddrages, hvorledes de eksisterende konkrete 
lagre af bevaret arv skal opretholdes og vedligeholdes, og hvilke nye institutioner der med basis i et specialiseret videnssamfund kan være påkrævet. Endelig drejer det sig om hvorvidt en politik for kulturarven specifikt vil bidrage til at gøre kulturpolitik generelt mere væsentlig og interessant for flere, evt. nye og andre grupper i samfundet end de bedst uddannede.

Skal en stat som den danske motivere et dynamisk politikområde som kulturarvens, ligger der dog også et problem $i$ at ajourføre en fremherskende tradition for nationsopbygning og integrerende national kollektiv identitetsopdragelse samtidig med dels en stadig mindre etnisk-kulturel homogenitet, dels en stigende tilslutning til et europæisk unionsfællesskab. Heroverfor er det blevet fremført at styrken ved at kende til og stå på sit eget giver styrke til at møde nyt; men dette - også politiske - svar kan næppe afbalancere dilemmaerne tilstrækkeligt. Hvis staten vil prioritere et ansvar for og rettidig synligg ørelse og anvendelse af kulturarv som identitetsfaktor (etnisk, sprogligt, religiøst mv.), er der formentlig grænser for $h v o r$ flertydig og løs bestemmelsen af kulturarven kan være, og hvor ikke-autoritative institutionerne kan fremstå. Staten nyformulerer næppe et politikområde for at tabe i tydelighed som nation hverken udadtil eller indadtil? Kulturarv som kulturpolitisk område kan således meget vel komme i konflikt med andre nyere kulturpolitiske målsætninger som decentralisering, kulturel mangfoldighed, pluralisme, demokratiske hensyn til indvandrergrupper, individuelle og lokale identiteter etc.

Officielt dukkede kulturarvsbegrebet op i 1984 i Museumslovens formål om "at sikre Danmarks kulturarv", hvor det bl.a. erstattede en tidligere formulering omkring den kollektive hukommelse. I 1986 blev samme formål gentaget i loven om Kulturvardiudvalget der - i lighed med praksis i andre lande - skal sikre at værdier, som regnes for betydningsfulde for dansk kulturel historie forbliver i Danmark og ikke må udføres. Der var en vigtig signalværdi i denne - længe ret upåagtede- lov som også søgte at indkapsle markedskræfterne i handlen med kulturværdier over landegrænser. (21) Som nævnt gik der dog flere år før man begyndte at eksplicitere begrebet.
I 1990ernes store kulturpolitiske betænkningsarbejde, Kulturens politik, drøftedes kulturarvsspørgsmål i relevante dele uden dog at spille nogen fremtrædende rolle. Således blev det først med kulturministerielle udmeldinger og konferenceinitiativer fra 1997 og frem at kulturarvsspørgsmålet formuleredes tydeligere, dels sammen med en identitetspolitisk tankegang og dels samtidig med at den truede bevaringssituation på mange områder blev mere åbenbar.(22) Det sidste årtis stigende fokusering og debat har således også afstedkommet ajourføringer af den relevante lovgivning. Sk $\varnothing$ nt teksten i hverken Arkiv- eller Biblioteksloven taler klart om kulturarv, er det blevet tydeligt at også disse områder sammen med Pligtafleveringsloven, Kulturværdiloven og Museumsloven, foruden lovgivning om bygnings- og landskabsbevaring og om fredningsforhold samlet henregnes til politikken omkring kulturarv.(23) Der er kommet et slagkraftigt retningsgivende samlebegreb til, og ordet kulturarvsinstitution er blevet mere almindeligt; således synes også en mere sammenhængende og ekspliciteret forvaltning af kulturarv at træde frem, skønt størstedelen af de formål og den praksis man har haft $\mathrm{i}$ institutionerne jo ingenlunde er nyopfundne. Denne skærpede sammentænkning spejler antagelig også en generelt øget tendens til politisk styring på grundlag af vordier.

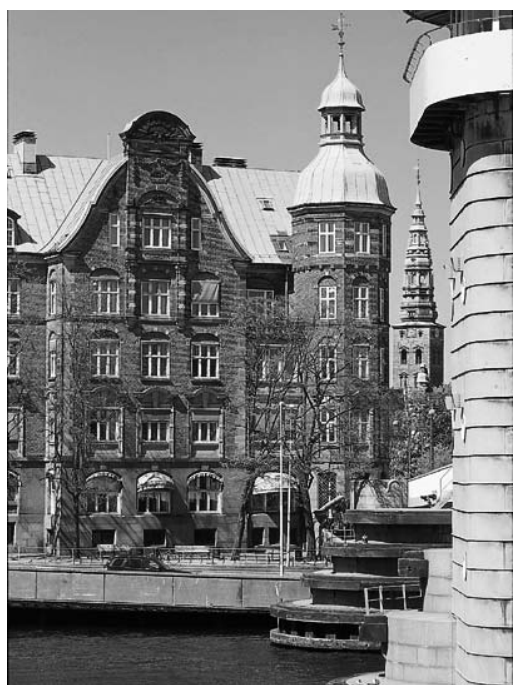

Den nye Kulturarvsstyrelse har til huse i Slotholmsgade $i$ Kobenhavn. Bygningen - kaldet Tietgens Hus - blev opført i 1900-03 som hovedsade for Privatbanken efter en nedrivning der gav anledning til de første drøftelser af behovet for en egentlig lov om bygningsfredning. 
I løbet af 2001 blev en planlagt ny museumsstyrelse omformet til en Kulturarvsstyrelse med etablering fra 2002. Den nye styrelse omfatter nu bygningsfredning og -bevaring, museumsvæsen, kulturværdisikring (Kulturværdiudvalget), arkæologi og nyere kulturhistorie samt kulturmiljøområdet, men formelt således ikke bibliotekerne og arkiverne. Ambitionen har været at samordne og styrke det samlede kulturarvsarbejde og give det en mere central og synlig placering med øget vidensopbygning og udviklingstiltag.(24)

Tilvejebringelsen af Kulturarvsstyrelsen var tillige et resultat af årtiers proces med forvaltningsmæssige strukturændringer og terminologiske justeringer i netop et samspil mellem politik, forvaltning og sektorforskning. Tænkningen i centralforvaltningen flyttede sig fra kvantificerende kortlægning i 1960-70erne frem mod dimensioner der lagde vægt på et holistisk og ideologisk perspektiv med sigte på identitetsspørgsmål og på formidling og oplevelse i de seneste årtier. Bevaringsholdninger blev mere fremtrædende samtidig med at kulturfag og naturfag - og kulturpolitik og miljøpolitik - nærmede sig hinanden; internationalt skiftede man eksempelvis 'Cultural Ressource Management' ud men begrebet 'Heritage Management'. Kulturmiljø (sporene af historien i de fysiske omgivelser) dukkede op som begreb og viste at der må tænkes bredere end de traditionelle kunstog kulturområder og humaniora-discipliner. Det skal næppe undervurderes at Miljøministeriets planstyrelse og fredningsstyrelse fra 1970erne (foruden miljøbevægelser generelt siden da) har spillet en dynamisk rolle; forskellige ressortskift mellem miljø- og kulturministerium og mange paralleliteter i $\varnothing$ vrigt mht. bevaring og genopretning understreger blot hvorledes både de fysiske omgivelser og det ikke-flytbare er en del af kulturog kulturarvsbegrebet.(25)

Således er denne politik udkrystalliseret af en stigende fler- og tværfaglig kulturarvstænkning mellem mange fagområder: arkæologi, historie, etnologi, kulturgeografi, landsplanlægning, kultursociologi, kunsthistorie mv. - i sig selv en væsentlig videnshistorisk udvikling, og der tilkommer fortsat nye relevante akademiske felter, fx kulturhistorisk informatik og turisme (begge Syddansk Universitet), ligesom en Kulturarvens forskersko- le etableres i tilknytning til biblioteks- og informationsvidenskab (Danmarks Biblioteksskole).

Et væsentlig tilskud har kulturarvspolitikken fået gennem bestræbelser på et $\emptyset$ get samarbejde mellem samfundets hukommelsesinstitutioner: arkiver, biblioteker og museer - det såkaldte $A B M$ samarbejde. Skønt disse kulturelle institutioner har meget til fælles, har der også trivedes meget separate og forskellige institutionskulturer og fagtraditioner, som har adskilt mere end samlet. De nye satsninger ses prioriteret i fx EU-programmet Information Society Technologies (IST) og det europæiske netværk af folkebiblioteker PULMAN. I England foretoges i 2000 en sammenslutning til: The Council for Museums, Archives and Libraries med vægt på strategisk samarbejde mellem sektorerne, og Norge har - under megen diskussion - i 2003 etableret en ny styrelse ABM-utvikling til fælles tiltag og samlet udnyttelse af historiske kundskabskilder efter funktionelle hensyn (dvs. brugerbehov).(26)

Bestræbelserne angår bedre og mere koordinerede strategier for hvad der skal bevares, øget tværfagligt samarbejde og synergi og styrket samlet profilering af disse hukommelsesinstitutioner kulturpolitisk set. Sammenlægningen i Danmark af Arbejderbevagelsens Bibliotek og Arkiv med Arbejdermuseet til én samlet institution på dette specialområde er et aktuelt foregangseksempel.

Udviklingen er ikke mindst drevet frem af de nye teknologiske muligheder i forbindelse med elektronisk registrering og indeksering af samlingerne (genstande, trykte skrifter, billeder, arkivalier etc.) samt den både $\varnothing$ nskede og påkrævede digitalisering af dem, idet der også kan arbejdes med fælles standarder til gavn for søgemuligheder. Foruden rationaliserings- og effektiviseringsgevinster i udnyttelsen af informationsressourcerne ligger der en både politisk og formidlingsmæssig strategi om en forbedret samlet adgang til hele kulturarvsområdet; det demokratiske aspekt i den frie og lige adgang er det vigtige.

I overensstemmelse med nyere formidlingstænkning er synsvinklen søgt vendt 180 grader og lagt hos modtageren; for den historieinteresserede borger og bruger er det relevante at få fat i de 
$\emptyset$ nskede informationer, mere end fra hvilken institution de stammer. Der lægges således op til en $\emptyset$ get brugervenlighed og servicetænkning fra hukommelsesinstitutionernes side. Heri ligger der adskillige nye perspektiver for oplysning, uddannelse og læring, som det kan ses i fx et projekt om et integreret historiecenter i Odense eller i nyformuleringer af lokale kulturpolitikker. Indtil videre ligner det i Danmark mindre vidtgående kulturpolitiske strategier end i fx Norge og England; men det synes evident at kulturarv som overordnet betegnelse har bidraget til et skærpet helhedssigte for denne forbedrede tilgængeligg ørelse af kilderne til historien.(27)

ABM-samarbejdet ligger også i den nyeste ministerielle redegørelse Udredning om bevaring af kulturarven (2003) der sammenfatter den nuværende tilstand og de forn $\varnothing$ dne indsatser for så vidt angår den flytbare kulturarv. Denne hidtil mest omfattende samlede danske tekst inden for officiel kulturarvsforvaltning godtg $\varnothing \mathrm{r}$ ligeledes at området teoretisk, organisatorisk og politisk set endnu er i opbygningsfasen.

Et hovedspørgsmål må fortsat angå det stadig tydeligere ændrede forhold til fortiden som politisk udfordring. På den ene side ligger den 'indkapsling' som mulighederne for faglig selektion, systematik, specialisering, standardisering og styring via institutionelle rammer og initiativer giver; uddannelses- og videnssamfundets ekspertstyrede forvaltning kan bringes til at intensivere en art officiel historiekultur, evt. instrumentalisere den yderligere; elementer kan i enklaver og ved passende lejligheder trækkes frem til visning og fejring; staten kan gå foran og andre mere eller mindre offentlige instanser følge efter. Heroverfor står på den anden side den 'frisættelse' af både social og psykologisk art som et stadig mere risikopræget og uforudsigelig mangfoldigt samfund præges af med fri tid, normopg $\varnothing r$, afdisciplinering, individualisering og liberale menneskerettighedsidealer, med fortsat mere flertydige begreber om både historie og hverdagskultur, med vidensmængder der vokser dag for dag - både fremad og bagud - og med distributionsprocesser som i nye dimensioner kombineres med uoverskuelige konsekvenser af en globaliseret medieudvikling.

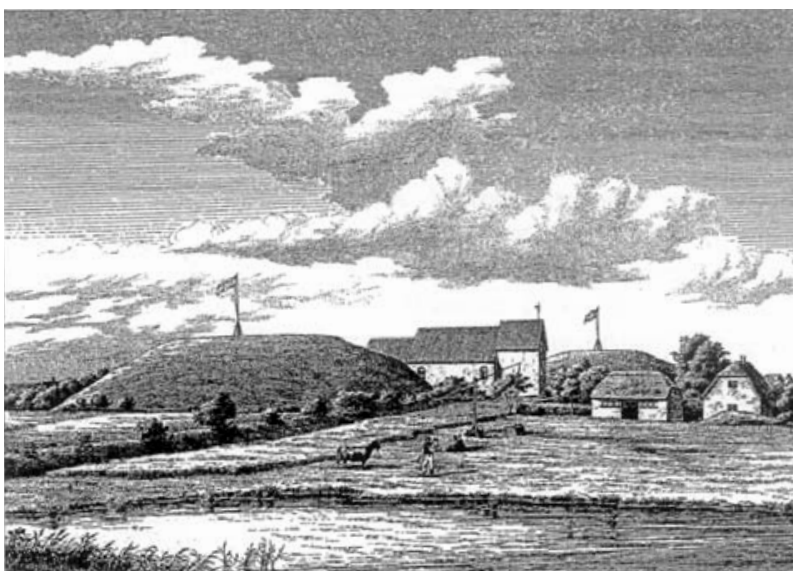

Kongehøjene i Jelling - tegnet af Jacob Kornerup i 1861. I 1994 blev højene optaget på UNESCOs verdensarvsliste, i 2000 åbnedes et nybygget formidlingscenter Kongernes Jelling og i 2003 gav det historiske sted med gravhøje, kirke og runesten motiv til en ny frimarkeserie fra Post Danmark.

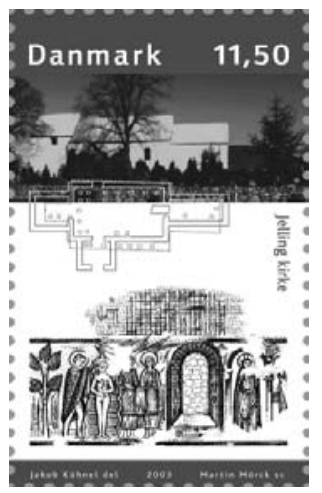

\section{Kulturarvsinformation}

Essentielt er det at sikring og bevaring af kulturarv modsvares af tilgængeligg $\varnothing$ relse og formidling. Sk $\emptyset$ t dette ikke er noget nyt hovedanliggende for de offentlige hukommelsesinstitutioner, synes kravet i stigende grad at blive åbenhed og tilgængelighed for hele befolkningen - ikke kun forbeholdt eksperterne. Informationen om den viden der skal ledsage og underbygge identifikation og opretholdelse af hvad der er, kan eller skal være kulturel arv stilles derved over for nye udfordringer. Dels fordi det ikke kun drejer sig om viden, men også holdninger, ideologier, følelser og identitet, dels fordi der er politiske krav om en stærkere formidling af informationen og endelig fordi der er nye muligheder for udbredelsen. Kulturarvstænkningen skærper kravene til håndtering af systematikkerne for informationsorganisation og processer - dvs. til indsamling, bevaring, ordning, tilgængeligg ørelse og formidling. 
Betoner man det politiske udgangspunkt for den kollektive erindring og identitet, kan et hovedanliggende i informationsformidlingen blive at afveje det holdningsbårne og emotionelle med det kognitive; lidt skarpt trukket op kan det formuleres som en folkelig fortrinsvis emotionel interesse over for en professionel fortrinsvis kognitiv interesse.(28) Samtidig med at kulturarvsinstitutionerne som videns- og forskningsbaserede har til opgave at sikre at de omtalte valg foretages på et så videnskabeligt dokumenteret grundlag som muligt, må de også reflektere og respektere strømningerne fra den nyere politiske og holdningsbårne fokusering af kulturarv. Den omtalte fetich- og totemkarakter ved kulturarven, ærbødigheden og symbolkraften, må også inddrages og belyses; spørgsmålet er om det også vil eller kan indebære at det hellige forvandles, undermineres eller forsvinder?

Denne udfordring indebærer antagelig at begrebet om videnstilegnelse må afbalanceres i forholdet mellem på den ene side kendsgerninger som er nødvendige og ikke kan vælges til eller fra, og på den anden side hvorledes vi kan vælge, hvad vi vil vide noget om og hvordan vi vil vurdere og bruge denne viden i refleksionen over den personlige, sociale og kulturelle identitet.(29) Måske agerer det såkaldte videnssamfund (netop) ikke alene ud fra viden?

Den forudsætter dernæst også nye tankegange inden for de traditionsorienterede fag, der blev organiseret som humaniora-fag ved dannelsesuniversiteterne fra 1800-tallet og frem, fx med omvægtning i retning af receptionsstudier.

Endvidere lægger udfordringen op til at informationsformidlingen ikke blot dokumenterer, vidensberiger og tilrettelægger faktuelt, men også ekspliciterer såvel en grundlæggende undren og spørgen som de bagvedliggende begrundelser hvorfor der gemmes og opbevares, arkiveres og magasineres, musealiseres og digitaliseres. Formidlingen må blive mere refleksiv. Nationalmuseets nyeste permanente udstilling betitles eksempelvis netop med flertalsformen: Danmarkshistorier - fordi der måske er mere end én monokulturel national historie.
Og endelig indebærer den at den vidensbaserede informationsformidling må besinde sig på, hvorledes moderne formidling tilsiger aktiv medleven og oplevelse, og herunder forholde sig til at historieoplysningen i ikke aftagende grad er et stort broget og delvis kommercielt marked.

Informationsformidling via elektroniske muligheder er derfor et nyt og politisk stærkt prioriteret felt. Siden 1980ernes nye faciliteter er der - i vekslende tempo - opsat nye, også lovbefalede, mål for samlet opbygning af museernes registreringer af samlinger. En stor del heraf sorterer nu under Kulturarvsstyrelsen; det gælder databaserne Fund og Fortidsminder (tidligere Det kulturhistoriske Centralregister, DKC) der registrerer arkæologiske fund og fortidsminder (lokaliteter), Kunstindex Danmark (KID) der registrerer kunstværker i danske museer og samlinger og Museernes Samlinger der er en central oversigt over registrerede genstande (incl. arkivalier, fotos mv.) fra nyere tid i danske kulturhistoriske museer (foreløbig kun 20 museer); et ganske nyt specialprojekt er eksempelvis Monument, Ideologi og Landskab der er et søgbart Danmarks-kort over mindesmærker og mødesteder mv. af national karakter initieret af Museet Sønderborg Slot.

På arkivområdet er Dansk Arkivalie Informations System (DAISY) med elektronisk tilgængeliggørelse af information om materialer i Statens arkiver under opbygning med nyskabende søgeindgange og overbliksmuligheder; for arkiver fra mere end 150.000 foreninger, virksomheder, personer mv. er der etableret søgeindgange via Danmarks Nationale Privatarkivdatabase (DANPA), og for de lokalhistoriske arkivers vedkommende via $A R K I B A S$ der er et fælles registreringsprogram drevet af Sammenslutningen af Lokalarkiver.

På biblioteksområdet har den elektroniske dækning resulteret bl.a. i Danmarks elektroniske forskningsbibliotek (DEF) der er netværket for forskningsbiblioteker og informationscentre (herunder således også for historisk viden) med sigte på samlet adgang for alle. Mere specielt findes $\mathrm{fx}$ Dansk Nationallitteraert Arkiv (DNA) på Det kongelige Bibliotek med digitalisering af ældre tekster, og på samme institution er der i 2002 i sam- 
arbejde med Det Danske Sprog- og Litteraturselskab åbnet et nyt Arkiv for Dansk Litteratur (ADL) som er et websted for klassisk dansk litteratur med solid tekstkritik, faksimilegengivelse, noter, forfatterportrætter og -bibliografier mv., der st $\varnothing t$ agtes udbygget til gavn for litteraturformidlingen.

Ved siden heraf ligger i centralt regi også fællesportalen Danske museer online med ambition om at blive en samlet indgang til danske statslige og statsanerkendte museer og deres samlinger - en slags virtuelt museum, foruden Kulturnet Danmark der samler formidling på internettet af dansk kultur - under Kulturministeriets ressort, herunder således alle de historisk orienterede institutioner og aktiviteter.

Regionalt og lokalt har adskillige ABM-institutioner taget fat med initiativer, således med to pilotprojekter åbnet 2002 Nordjyllands Kulturhistoriske Søgebase (NOKS) og historiefyn; begge søger de med tværinstitutionelt sigte og med lidt forskellig både faglig og søgemæssig profil at afprøve mulighederne for fælles standarder og fornyende præsentationer af institutionernes registreringer, herunder med digitalisering af lyd og billeder; samtidig med et mål om forbedring af den samlede adgang til samlinger appelleres der også til en bredere alment historieinteresseret kreds end fagfolkenes. Noget lignende gælder Historisk Billedarkiv - danskebilleder.dk der efter udenlandsk inspiration er etableret af en række større folkebiblioteker på basis af lokalhistoriske samlinger med støtte af År-2000 Fondens kulturprojekt "...herfra min verden går. Dansk identitet i fortid, nutid og fremtid"; formålet er dels at bidrage til et ABM-samarbejde, dels at udvikle en billeddatabase som "et af flere elementer i en kommende portal over den nationale kulturarv", som det hed i vedtægterne fra 2002. På lokalt niveau findes også tiltag som fx det elektroniske Århus Leksikon med bl.a. stor vægt på stof fra Lokalhistorisk Samling (folketællinger, vielsesdata fra kirkebøger, borgerbøger, matrikelnumre mm.).

En periodeafgrænset portal kan eksemplificeres ved Guide til dansk guldalder med introducerende oversigter og en mængde links til stof om tidsrummet 1800-1850 og udviklet under Golden days in
Copenhagen som paraply for hovedstadens kulturarvs- og turistinstitutioner. Dansk Historisk Fællesråd er tilsvarende paraply for den ganske nye fælles formidlingsportal historie-online. $d k$ som søger at samle allehånde typer foreninger og institutioner (ca. 70) med virkeområde inden for historie; med vægt på nyheder fra hele den historiske verden og på videreguidning af de interesserede sigtes der på et 'udstillingsvindue' der rummer såvel forskningsformidling som debatmuligheder og synergipotentiale blandt både amatører og fagfolk.(30)

Blandt de her nævnte er der både pilotprojekter og fors $\varnothing \mathrm{g}$, til mange store og $\varnothing$ nskede sammenkoblinger er der endnu blot lagt skinner ud; nogle har været under opbygning siden 1980erne, men først fra midten af 1990erne og i de allerseneste år er hele denne satsning og styring med forbedret teknologi og økonomi blevet tydelig. Informationssituationen er i løbet af ganske få år ændret så meget at den i sig selv kan siges at være en dynamisk - og demokratisk - faktor i kulturarvstænkningen.

Perspektiverne er flere. Stadepladsen er blevet fornyet for flere ældre etablerede forsknings- og formidlingsinstitutioner, som havde levet en lidt trykket tilværelse under den spektakulære mediekultur i de forudgående årtier. Meget af hvad der hidtil har været godt skjult for andre end fagfolks $\varnothing j n e$ kan nu åbnes op; for de offentlige bevillingsgivere sættes det som en stadig tydeligere betingelse at ressourcerne kan legitimeres af $\varnothing$ get tilgængelighed for befolkningen. Den faglige dokumentering, registrering og systematisering har således fået indarbejdet en mere dynamisk tænkning $\mathrm{i}$ formidling og præsentation end der ofte ellers har været tradition for.(31) Denne udvikling i demokratiserende retning må medføre nye inspirerende arbejdsopgaver for mange historie-fagspecialister af forskellige slags og nye indgangsveje for amatørerne. Alment historieinteresserede og fagfolk har nærmet sig hinanden; nogle skel kan nedbrydes til gavn både for tendensen hen imod mere individuel og selvvalgt historieformidling og for nye muligheder i det civile samfunds organiseringer og samarbejde med offentlige kulturinstitutioner. Eksempelvis har biblioteksorganisationen IFLA i 2002 underst $\varnothing$ ttet et nyt felt 
med oprettelsen af en sektion Genealogy and Local History for at imødekomme den stigende folkelige interesse for bl.a. slægtsforskning.

Væksten af elektroniske informationer har skabt mulighed for et forbedret samlet overblik over kilder til historien, herunder også synliggjort 'huller og mangler'; der er blevet og bliver åbnet op for hidtil uanede eller utilgængelige lagre og magasiner, og der gives bedre mulighed for at holde forskellige institutioners specifikke traditioner og særegne procedurer op mod hinanden. Ligeledes bliver det synligt hvad der ligger af solide ressourcer til brug for tilrettelæggelse af specifik og fleksibel information omkring (kommerciel) kulturarvsturisme.

Med eller uden koordinering af Kulturarvsstyrelsen - det synes oplagt at kulturarv fungerer som et samlebegreb, og i hele denne opbygning kan man se argumentationen omkring den nationale kulturarv anvendt både eksplicit og implicit. Mange nye initiativer har haft de eksisterende nationale institutioner og samlinger som udgangspunkt for den øgede kortlægning, sammenkobling og synliggørelse af kulturhistorien. Både den geografiske sammentrækning og den øgede tilgængelighed har i følge med teknologien således revitaliseret nationens kulturelle historie. Det er blevet lettere både udadtil og indadtil at skilte med en synlig samlet fond af national fortid; en art central officiel kulturarv ligger nærmere for nu - og måske derved også en nationernes konkurrence på selvfremvisning, som i tiden før Første Verdenskrig! I den internationale arbejdsdeling, hvor hver nation er forpligtet på i hvert fald sit eget, er denne synligg ørelse af det nationale sket i en udfordrende dialektik, for samtidig med internationaliseringen og den europæisk integration er problematiseringen af nationalstaten også blevet øget.(32)

Når historien og kulturarven således ud fra politiske krav om formidling skal tilgængeligg øres elektronisk, rejser det yderligere spørgsmål. Hidtidige faglige traditioner og indarbejdede systemer omkring klassifikation og ordning kan blive anfægtet af krav eller $\varnothing$ nsker om homogenisering, digitale standarder og kompatibilitet og dermed aff $\varnothing$ de nye diskussioner med implikationer langt ud over ud over det rent tekniske, fx når den elek- troniske repræsentation skal erstatte museumsgenstandenes autenticitet. Det gælder spørgsmål om hvorvidt hensyn til forvaltning og styring eller til eksponering (og evt. politisk korrekthed) vil overskygge videnskabelig faglighed. Problemstillinger af den art stilles både praktisk og teoretisk, og inden for både de forskellige traditionelle historiske fagfelter og det informationsfaglige felt - de har med kulturarvsinformationen nærmet sig hinanden.

Når informationsspecialister bidrager til at udvikle de nævnte baser og registre, til at udbrede dem og præge brugen af dem, er det samtidig nødvendigt at de forholder sig til både hele det vidensorganisatoriske grundlag for dem og den bagvedliggende historietænkning og ideologi. Disse skærpede informationssammenhænge angår ikke blot fx musik, litteratur og malerkunst, områder som byog landsskabsplanlægning og kulturmiljø må også indbefattes i kulturarvsinformation. De kortlægninger $\mathrm{i}$ form af kommuneatlas (dokumenteret med fotos, kort, beskrivelser mv) der er fremkommet siden ca. 1990, og som samtidig inddrager befolkningen i bevaringsspørgsmål, kan anføres som et vedkommende felt (af de ca. 75 kommuneatlas findes flere også i en netversion).(33)

Kulturarvsbegrebet har for hukommelsesinstitutionerne været en bevillingsudløsende mellemproportional mellem forskningsudvikling og bred demokratisk formidling. Det vil i stigende grad også for folkebibliotekerne og de lokale arkiver og museer være en udfordring at forholde sig til denne værdiladning; bl.a. drejer det sig om hvilke værdier der ligger bag brugernes og de besøgendes motivationer, spørgsmål og adfærd, og hvorledes de kan modsvares af saglig dokumenteret, gerne videnskabelig, information. Kulturarv kunne være et motiverende omdrejningspunkt i en spørgende form: "Er dette her kulturarv?"; hvorefter både accession, boglister, udstillinger, samtaler, ordning af viden og materialer mv. så stilles til rådighed for uddybet stillingtagen på et vidensmæssigt højere niveau omkring fortidens stof og spor. Det kan være en pointe at informationsformidlingen derved ikke tager udgangspunkt i et objekt, men i noget som objektet skal sættes i relation til. Kulturarv kan anvendes som et spørgende overbegreb. 
Et eksempel: Stiller man spørgsmålet "Hvad er Carl Nielsens musik?", kan der gives nogle svar som peger ind i objektet, og de kan udmærket betragtes som formidling af noget historisk. Stiller man spørgsmålet "Hvad kan Carl Nielsens musik sige os i dag?", peger det på en relation mellem et fortidigt objekt og den nutid der må tage stilling; svarene her vil indbefatte en både anderledes og udvidet historisk formidling. Men ved at stille spørgsmål som "Er Carl Nielsens musik en del af kulturarven?" eller "Hvorledes er Carl Nielsens musik en del af kulturarven?" kunne der nås et yderligere udgangspunkt for formidling; fordi man indfører en overordnet st $\varnothing$ rrelse som resonans og ramme både for oplysninger og stillingtagen. Ganske vist en meget elastisk størrelse, men én der tvinger til at medtænke hvordan kulturen forvaltes og overføres, og som fremhæver at noget kun bliver vedligeholdt, hvis nogle på bestemte betingelser og med bestemte viljer har gjort det og fortsat gør det. Spændet mellem denne musiks produktionsår (ca. 1900-30) og i dag, hvor man skal forholde sig til om den er kulturarv, kan derved blive tydeligere. Det er her i nutiden vi skal forholde os til, om det er en arv vi vil vedgå. Tilmed kunne sådanne spørgsmål i tilfældet Carl Nielsens musik måske ligefrem bidrage til at synligg øre forskellige tilknytninger og vægtninger: på den ene side til den etablerede musikhistorie der foruden musikanalyse også omhandler dels det socialt set snævre musikliv med konservatorium, musikforening og kongeligt kapel Nielsen begik sig i, dels den smagsmæssigt svingende diskussion omkring hans kompositioners efterliv; og på den anden side den vidstrakte tradition for hans sangbare melodier med den kontinuerlige brug og folkelige symbolværdi. Der er flere arvelag omkring den Carl Nielsen, hvis portræt findes på den officielle hundredekrone-seddel; der er et specialmuseum i Odense, der en populær biografisk spillefilm i biograf-, tv- og videomediet, der er forskningstunge dokumentarier samt utallige nyindspilninger i koncertsale og i musikhandelen. Måske er det ikke helt den samme kultur alle har arvet eller som i lige grad er arvet efter ham. Det kunne springe i øjnene ved at 'stille kulturarvspørgsmålet' til hans musik - som kritisk spørgsmål til hvem der har defineret kulturen.(34)
Ledsagefænomenet til den $\emptyset$ gede information om kulturarven er af identitetspolitisk art. Den vægtning kulturpolitikken har foretaget af det historiske - en vægtning den ikke havde i samme grad ved sin fremkomst i 1960erne - har også fået den til at træde tydeligere i identitetspolitisk karakter. Den informationsformidling der som en del af en politisk satsning har fået nye muligheder angår således ikke blot vidensressourcer og vidensformidling, det er også identitetsressourcer og identitetsformidling der er blevet fokuseret. Det er en udfordring for informationsvidenskaben at forholde sig hertil.

\section{Arv og gald}

Samtidig med at kulturarvsbegrebet er et reaktivt samlebegreb, er det også produktivt. Det kan anskues som et frugtbart begreb fordi det med mange indfaldsvinkler er åbent og uafklaret, og fordi det er involverende og aftvinger stillingtagen - der er partstænkning i kulturarv. I både kulturog informationsformidlingen kan kulturarvsbegrebet bidrage til at revitalisere holdninger og bringe vardier på banen midt i den stigende automatisering, kvantificering og inerti der ellers præger store dele af samfundets informationsflow.

I forholdet mellem en $\varnothing j$ jensynlig stigende interesse for historie og historisk identitet bredt i befolkningen og de historiefaglige ekspertisers forskning og udvikling sætter kulturarven nye valører på tilgængeligg ørelsen af viden og information. Omfanget af tilgængeligheden - især via de elektroniske faciliteter - skaber og kræver nye former for vejledning og nye muligheder for specialisters tilrettelæggelse og formidling af information. Ikke mindst i de lokale ABM-institutioner kan bibliotekarer, arkivarer, museumsfolk og kulturformidlere - med eller uden netsteder - indgå i nye konstellationer og samarbejde med foreninger og organiseringer i det civile samfund. Nogle af traditionerne fra den tidlige folkeoplysnings demokratiske forankring - som ikke kun drejede sig om offentlig institutionalisering - kunne herved forbindes med den nyere kulturarvstænkning. Desto mere man har sagt "vor kulturarv" eller "den fælles kulturarv", desto mere øges de risici der ligger $i$ at kassere eller lade hånt, i at ødelægge eller hindre fremtidig tolkning. Desto mere man under- 
streger demokratiet, desto mere bindes man til at bevare og tilgængeligg øre frit for alle og uafhængigt af magt, økonomi eller evt. øjeblikskonjunkturer. Kulturarvstænkningen bindes således til store omkostninger til denne bevaring - og må således også vedgå den gæld der ledsager arven.(35) Man tvinges ind i en politisk set $\varnothing$ mfindtlig balanceakt der kun kan befordres ved en essentiel refleksiv dialog mellem fagfolk og befolkning. Demokratiaspektet bliver fortsat fundamentalt for også hele informationshåndteringen, både konkret og teoretisk, praktisk og mentalt.

Der findes en personlig og lokal kulturarv i det mere nære perspektiv - grav hvor du står!(36) og en global kulturarv i det større perspektiv. Dog synes det at være kulturarv forbundet med nationen og det nationale der for tiden samler den mest handlekraftige politiske energi; derfor er det måske den som det informations- og formidlingsmæssigt er vigtigst at bearbejde kritisk - i forhold til den store gaeld der også har belastet hele den nationale tænkning.

Kampen om retten til at fortolke fortiden og vurdere hvilket indhold en historiebevidsthed og en kulturel arv bør have foregår hele tiden, alle steder og med mange involverede. Det er nødvendigt at bevæge sig ind i begrebets forhold til såvel de ældre samfundsmæssigt virksomme traditioner som dets nyere komplekse brug før man kan informere om og formidle kulturarven. Information om kulturarven må hvile på en forståelse af dens politiske mening.

\section{Noter}

1. Beckman (1999) s.49.

2. Poltiken 7.12.2001; Kristeligt Dagblad 3.1.2002; www.goldendays.dk; www.klassikerdagen.dk; Kritisk forum for praktisk teologi, juni 2003, s.71ff; www.chwb.org/sve; www.skansen.koti.pl; www.whc.unesco.org; www.vorfaellesarv.dk; www.europanostra.dk.

3. Fx A. Giddens: Modernitetens konsekvenser, 1995 (1990); Global etik (1998); Y.Raj Isar: Collision Course. Heritage Preservation versus Demands of Modernization, i: The Chal- lenge to Our Cultural Heritage, Paris, 1986; Bryld (1999); Wollan (1999) s.195ff.

4. Dansk identitet i det 21. århundrede [Elsebeth Gerner Nielsen], konferenceoplæg sept. 1999.

5. Fx Hodne (1994); Dansk identitetshistorie 1-4, O. Feldbæk (red.), 1991-92; Jensen (1996); Howard (2003) s. 166ff.

6. Bryld (1999); B. E. Jensen: Historie - livsverden og fag, 2003.

7. P. Porskær Poulsen: Vi passer på historien. En undersøgelse af lokalarkiverne, SLA 1997; Floris og Vasström (1999).

8. Bryld (1999); fx J. Beinov mfl.: Globaliseringens $A B C, 2002$.

9. Jfr. Wollan (1999); Howard (2003) s. 102ff.

10. Birkebæk (2002); Beckman (1999); Witt (1998); Howard (2003); Bohman (1999).

11. National Heritage Conference i Storbritannien i 1983, jfr. R. Hewison: The Heritage Industry, Lond. 1989 s.6.

12. Jfr. fx Hodne (1994) ss. 23f, 166ff og Global etik (1998).

13. Lowenthal (1994) s.49.

14. Beckman (1999) s.54.

15. O. Löfgren i: Kulturmiljø (2002) s. 61.

16. Beckman (1999) s.59ff.

17. Beckman (1999) s.72f.

18. Howard (2003) s.12; www.hf.uio.no/iks/forskning/kulturarv.

19. Bevar din arv. 1937 - Danmarks fortidsminder 1987, I. Nielsen (red.), 1987; Hodne (1994); Dansk Identitetshistorie, 1991-92; Beckman (1999) ss.47ff, 79f; Howard (2003) ss. 130ff, $166 \mathrm{ff}$. 
20. Fx C. Bryld: Kampen om historien. Brug og misbrug af historien siden murens fald, 2001.

21. Kolding Nielsen (2001).

22. P. Duelund: Den danske kulturmodel: en idepolitisk redegørelse, 1995; Redegørelse til Folketinget om kulturpolitik 4.11.1997; Dansk identitet i det 21. århundrede, konference sept. 1999; Folketingets Kulturudvalgs høring om Bevaring af kulturarven - 25.4.2001; Kulturens forskning 2001-2004, 2001; Cult 2001 - Exploring an interface between Cultural heritage, Net art and State of the Art projects, konference okt. 2001.

23. Lov om sikring af kulturværdier i Danmark af 4.6.1986; Lov om pligtaflevering af udgivne værker af 10.6.1997; Lov om biblioteksvirksomhed af 17.5.2000; Lov om bygningsfredning og bevaring af bygninger og bymiljøer af 7.6.2001; Museumslov af 7.6.2001; Arkivlov af 17.12.2002; jfr. Lov om forskning ved arkiver, biblioteker, museer mv. af 27.3.1996; jfr. også fx Den trykte kulturarv, 1999, forord.

24. Hvass (2002); www.kuas.dk.

25. K. Kristiansen i: Kulturmiljø (2002); jfr. Wollan (1999) s.199ff.

26. www.cordis.lu/ist/home.html; www.presentations.aakb.dk/pulmanguidelines; www.resource.gov.uk; www.abm-utvikling.no; Jfr. Kjelder til kunnskap (1999).

27. Historisk Center Odense 1. delrapport, Arbejdsgruppen vedrørende etablering af et historisk center i Odense, juni 2001; Udredning om bevaring af kulturarven (2003) s.111ff; Bohman (1999).

28. Jfr. Beckman (1999) s.56.

29. Jfr. S. E. Larsen: Den besværlige dannelse, Politiken. 27.6.03 (kronik).

30. www.dkconline.dk; www.kid.dk; www.kulturhistorieonline.dk; www.monument.dk; www.sa.dk; www.danpa.dk; www.lokalarki- ver.dk; www.deflink.dk; www.adl.dk; www.dmol.dk; www.kulturnet.dk; www.noks.dk; www.historiefyn.dk; www.danskebilleder.dk; www.aakb.bib.dk; www.goldendays.dk; www.guldalder.dk; www.historie-online.dk; jfr. bl.a. R. Falk Nielsen og M. Nielsen: Kulturarven på internettet: Nordjyllands Kulturhistoriske søgebase og historiefyn, i: Journalen 4/2002 [2003]; P. Porskær Poulsen: www.historie-online.dk - den historiske nyhedssite, $\mathrm{i}$ : Danske Museer 2/2003; Et nyt digitalt arkiv for dansk litteratur, v. ADL-redaktionen, i: Bogens Verden 5/2002.

31. Jfr, Bryld (1999) s.189ff.

32. Jfr. Adriansen (2003) s.23ff.

33. Fx Bornholm. Atlas over byer, bygninger og miljøer, 2003, udg. af Kulturarvsstyrelsen, jfr. www.kma-bornholm.dk.

34. Gyldendals musikhistorie, 1984, bd. 4 s.221ff; Adriansen (2003) I s.268f, II s.73f; J. Fellow: Carl Nielsen til sin samtid 1-3, 1999; Erik Clausen: Min fynske barndom, ASA Film, 1994; jfr. fx J. I. Jensen: Carl Nielsen - danskeren, 1991.

35. Howard (2003) s.221.

36. Fx C. Paludan-Müller: Historien omkring os arv og miljø, i: At bruge historie- $i$ en sen-/postmoderne tid, B. E. Jensen (red.), 2000.

\section{Litteratur}

Adriansen, I. (2003): Nationale symboler i det danske rige 1830-2000 I-II

Beckman, S. (1999): Vad vill staten med kulturarvet?,i: Kulturarvet, museerne och forskningen: rapport från en konferens 13-14. november, 1997, A. Alzén och M. Hillström (red.), Stockholm.

Bevaring af kulturmiljфet - håndbog (1999) v. K. Hybel Bräuner

Birkebæk, F. (2002): Kulturarv - et relativt begreb, i: Magasin fra Det kongelige Bibliotek nr. 3 
Bohman, S. (1999): Kulturarvinstitutionerna och det demokratiska arvet, i: Demokratins estetik, SOU, Stockholm.

Bryld, C. et al. (1999): At formidle historie - vilkår, kendetegn, formål

Floris L. og Vasström, A. (1999): På museum mellem oplevelse og oplysning

Global etik. Kulturens Brundtlandrapport. Rapport fra Verdenskommissionen for kultur og udvikling (1998) (Our Creative Diversity, Unesco, Paris, 1995)

Hodne, B. (1994): Norsk nasjonalkultur. En kulturpolitisk oversikt, Oslo

Howard, P. (2003): Heritage. Management, Interpretation, Identity, London

Hvass, S. (2002): Kulturarvsstyrelsen, i: Danske museer nr. 2-3

Jensen, B. E. et al. (1996): Erindringens og glemslens politik

Kjelder til kunnskap og oppleving: om arkiv, bibliotek og museum i ei IKT-tid og om bygningsmessige rammevilkår på kulturområdet (1999), Kulturdepartementet, Oslo
Kolding Nielsen, E. (2001): Kan det nytte. Om bevarelsen af kulturværdier for Danmark?, i: Bogens verden nr. 2

Kulturmiljø-mellem forskning og politisk praksis (2002). Seminarrapport, Institut for Arkæologi og Etnologi, Carlberg, N. og Møller Christensen, S. (red.), Københavns Universitet

Lowenthal, D. (1994): Identity, Heritage, and History, i: Commemorations. The Politics of National Identity, J. R. Gillis (ed.), Princeton

Poulsen, M. (1999): Kulturarv som didaktisk udfordring, i: Forskningstidsskrift fra Danmarks Laererhøjskole nr. 4

Udredning om bevaring af kulturarven (2003), Kulturministeriet

Witt, T. (1998): Kulturarv - hvad taler vi om?, i: Nordisk museologi nr. 1

Wollan, G. (1999): Kultur, turisme og samfunn. Kultur som romlig produksjonsfaktor i det posttradisjonelle samfunn. Om grunnlaget for heritageturismens framvekst, Trondheim

Kulturarvsstyrelsen - www.kuas.dk 


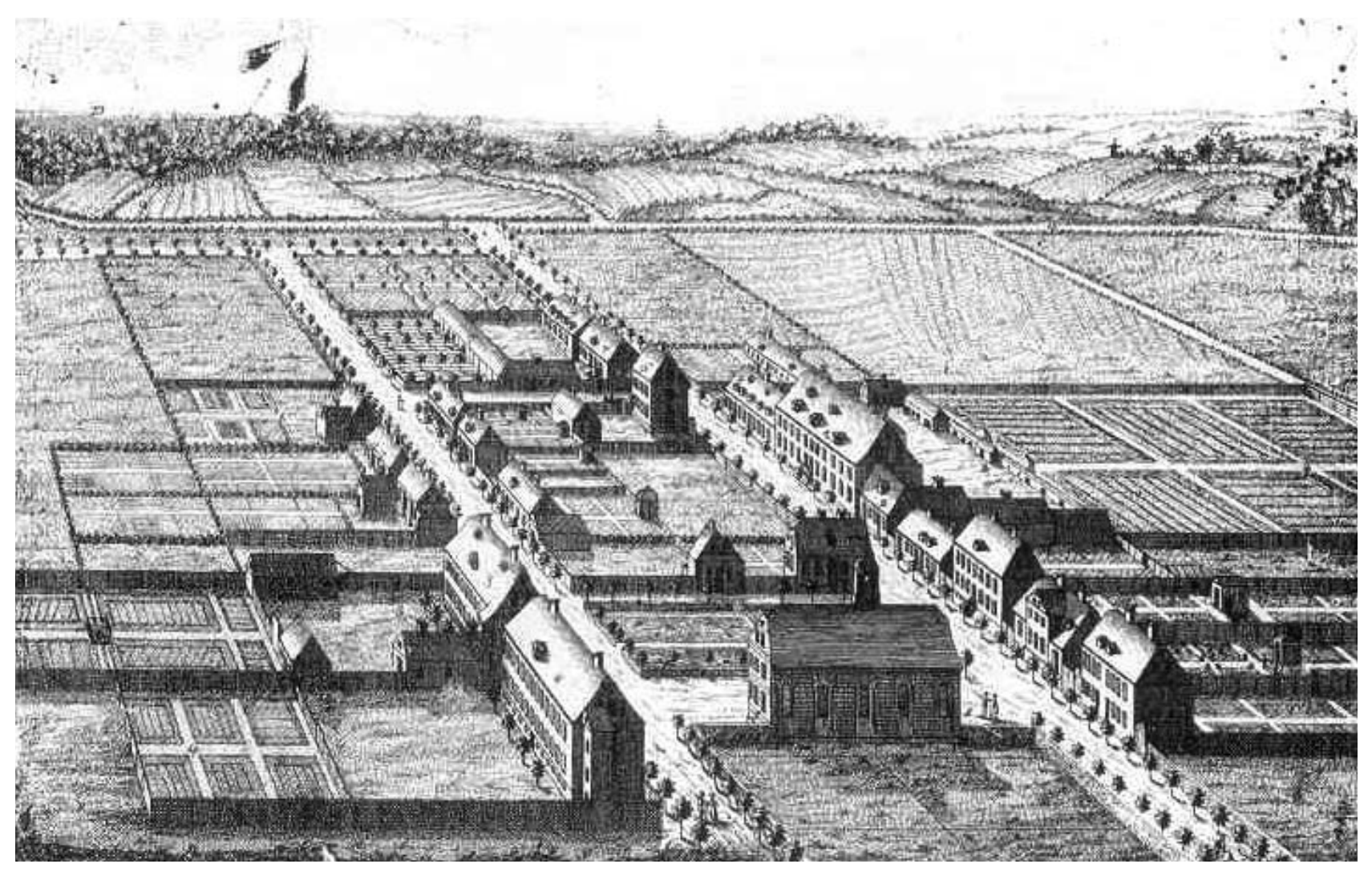

Christiansfeld - her gengivet på stik af Meno Haas fra 1780 - blev efter udenlandske forbilleder og nye planidealer, og med gennemført arkitektur og håndvark rejst på bar mark efter grundlaggelsen i 1773. Byen har navn efter Kong Christian VII der фnskede udvikling $i$ det sфnderjyske område og gav koncession til den driftige reformerte herrnhutiske brødremenighed. I dag regnes den blandt de bedst bevarede gamle brødremenighedsbyer $i$ Europa, og en igangvarende og fortsat planlagt restaurering har bragt den under observation til optagelse på UNESCOs verdensarvsliste. (Efter: Christiansfeld. Det Regionale Faglige Kulturmiljøråd for Sфnderjyllands Amt, nr.1, 2000) 